\title{
Environmental Governance and Public Participation
}

\section{Katerina Bozhinova}

Katerina Bozhinova, 23, is a graduate who received her Bachelor degree in "Political Science and International Relations" with honors at the American University in Bulgaria in 2014. She completed her Bachelor Thesis on Environmental Governance and Public Participation in 2014. Her interests include local environmental governance, policy-making, and comparative politics. This research was conducted as part of the final dissertation at the American University in Bulgaria. This author is grateful for the university support in accessing academic resources and would like to thank. Dr. Cosmina Tanasoiu for her constant feedback, supervision and support during this process.

\begin{abstract}
Environmental sustainability is a complex term, characterized by dynamic interactions between human and natural dimensions. Policy-makers in the developed world face the challenge of balancing economic growth with citizen concerns for curbing human impact leading to environmental degradation. This thesis contributes to the investigation of environmental governance on local scale by assessing the quality of environmental decisions. It examines and compares how the involvement of interest groups and citizens into local decision-making structures promotes efficient environmental policies. By applying the crispy sets qualitative comparative analysis (cs/QCA), this study aims to indentify the conditions necessary and sufficient for formulating participatory environmental decisions. The results suggest that successful policy formulation is dependent upon the presence of governmental agenda-setting and multilevel governance. The findings outline good practices, which reveal how governments can organize and facilitate participatory decision-making to ensure legitimate representation of interests and, thus, reach consensus-based decisions, which then translate easily into policy formulation.
\end{abstract}

Keywords: Developed World; Environmental Governance; Policy-Making; Public Participation; Qualitative Comparative Analysis. 


\section{Introduction}

Since the 1970s governments in developed countries reconsidered their approaches to managing environmental problems. Ruling elites increasingly promoted ideas of collaborative and participatory governance in search for more sustainable and effective policies. This shift in environmental policy resulted in the aftermath of the year United Nations Stockholm Conference and the United Nations Conference on Environment and Development in Rio de Janeiro. The Rio Declaration set out to protect the Earth's ecosystem, and committed developed countries to acknowledge their responsibility for pursuing sustainable development on a global scale (Vonkeman 2000). Sustainable development, developed by the United Nations, as a way of organizing human activity on our finite planet emerged as a political concept. Since there are no absolute criteria to optimize economic development while preserving the environment, sustainable development reflects human values and judgments, which requires opening environmental decision-making processes to wider groups, rather than governments and experts.

This thesis investigates how local environmental governance and participatory decision-making influence governance effectiveness in selected cases across the developed world. More particularly, it is examined how citizens and interest groups participate in environmental governance and evaluate their contribution to good governance practices. This study also considers contextual factors (i.e. economic, social, and political) and their role in influencing different actors' demands, decision-making processes, and environmental outcomes. The crispy sets qualitative comparative analysis (cs/QCA) is applied for sixteen cases, to identify conditions necessary and sufficient that characterize a good practice. This is a comparative study following the Most Similar Systems Design (MSSD), selecting cases that share characteristics such as similar structural characteristics, citizen involvement and generated outcomes of decision-making from both North America and Western Europe. This dataset relies upon secondary data collected from an on-going research project called ECOPAG (Environmental Consequences of Participatory Governance).

\section{Literature Review}

Environmental problems are complex and affect multiple agencies and actors. Their solutions increasingly incorporate public participation, representing a diversity of knowledge and values. Widespread acceptance of participation has partly resulted from increasing knowledge and interest in environmental issues, as well as policy trends that promote sustainable development and collaborative problem-solving. Claims in favor of participation, however, have rarely been 
tested, and no consensus on public participation as panacea to environmental sustainability exists.

\section{Environmental Governance and Public Participation}

Environmental governance is a multifaceted term, which includes social, institutional, and environmental elements. Governance is broadly defined as "the structures and processes by which people in societies make decisions and share power" and "creating the conditions for ordered rule and collective action or institutions of social coordination," to discuss how they apply for environmental problems (Folke et al. 205: 444). The normative dimension of environmental governance relates to promoting sustainable development (Hempel 1996; Gibson et al. 2005). A narrower approach focused on the management of fisheries, sees environmental governance as "the whole of public as well as private interactions taken to solve societal problems and create societal opportunities" (Kooiman and Bavinck 2005: 17). Kooiman and Bavinck (17) view governance as an inclusive term, which borrows from the literature on environmental policymaking and management both theoretical and practically-oriented mechanisms. More specific definitions emphasize on the institutional aspect of environmental governance as a "set of regulatory processes, mechanisms and organizations," which deal with environmental conflicts (Lemos and Agrawal 2006: 298; Paavola 2007: 97).

Literature on the theoretical aspects of environmental governance offers conceptualizations of different models of governance and examines how they shift over time. The three ideal types are hierarchical (or top-down) governance, self-governance - without intervention from governments, and co-governance, which is at the focus of this study, as it defines the interactions between governments and societal actors (Kooiman and Bavinck 2005: 21-22). Glasbergen suggests five different models of governance: market regulation, civil society, co-operative, contextual control, and self-regulation (1998: 3-4). In practice, a degree of hybridization exists, as these types of governance are not mutually exclusive and often operate together (Meadowcroft 1998). The major determining factors of governance hybridization and shifts across time are the number of the actors involved and the extent to which environmental issues affects them (Driessen et al. 2012: 145).

Collaborative types of governance, using participatory approaches such as meetings with stakeholders and engaging citizens in workshops, have become increasingly popular (Folke et al. 2005). Co-governance is based on public participation, which is defined as "any type of inclusion of non-state actors, as members of the public or as organised stakeholders, in any stage of 
governmental policy making, including implementation" (Wesselink et al. 2011: 2). Usually, governmental agencies initiate this mode of governance by developing agendas for meetings and natural scientists analyze environmental problems and develop solutions. This mode incorporates the public into an already established framework, which limits the discourse with them and simplifies social dynamics (Folke 2005: 462). Public participation, however, is not always limited to governmental and expert frames, which is evident in the first typology, crafted by Arnstein, which she called the "ladder of participation" (1969). The ladder begins from the lowest level of participation - passive dissemination of information for the purposes of education (also called "manipulation"), followed by other types of increasing involvement, the highest level of which means citizens obtaining the majority of the decision-making seats or the full power to decide, labeled "citizen control" (Arnstein 1969: 217). Other typologies distinguish between normative and pragmatic participation. Normative participation guarantees the democratic right of citizens to participate in environmental decision-making, while pragmatic participation is concerned with achieving high-quality decisions (Reed 2008). The distinction between the two types is framed as "public acceptance" versus "decision quality" or "political" versus "technical" participation (Beierle 2002: 3).

The benefits of public participation in environmental governance are approached from both normative and pragmatic perspectives. The normative argument for participation, grounded in democratic logic (enhancing representativity and legitimacy), claims that stakeholder involvement reduces the marginalization of society units. If participatory processes are perceived as fair and taking into account conflicting views, then they may increase public trust in decisions (Reed 2008: 2421). Participation promotes transformation of adversarial relationships by appreciation of other's views through social learning (Reed 2008: 2421). Pragmatic arguments focus on the quality and durability of co-governance decisions (see for example: Beierle 2002; Reed 2008). Cogovernance may enhance the rate of adoption of a decision and meet the local needs (Rydin and Pennington 2010: 155). By taking into account local concerns and interests, a project design may be enriched with locally specific information, unavailable to professional agencies. For example, environmental planning can benefit from detailed knowledge of the local environment and its use by local communities (Rydin and Pennington 2010: 155). Participatory processes can lead to high-quality decisions, as they are based on more complete information and negative scenarios can be analyzed and ameliorated before they occur (Reed 2008: 2421). Participation is also advocated to reduce conflict during policy-making and implementation. Engaging citizens at an early stage of policy processes can prevent from disagreement later on and guarantee greater legitimacy (Rydin and Pennington 2010: 155). 
The benefits of co-governance are counterbalanced by claims of potential dangers and dysfunctionalities. Cooke and Kothari warn about the dangers of groupthink, manipulation, selfcensorship, and coercive persuasion in participatory processes (2001: 11). Consultation fatigue may develop, as citizens are often asked to participate in environmental decision-making, in which they perceive little reward or capacity to influence, leading to a decrease in the quality of the participatory input (Reed 2008: 2421). Fatigue can be observed when participants' empowerment is restricted, which occurs most frequently when decisions are overruled by authorities. The reliability of participation is also questioned, as publics do not have sufficient expertise to deliver meaningful contribution, especially in technical debates (Fisher and Young 2007).

Research on citizens' contribution to high-quality environmental decisions is limited, especially regarding generalizations about the effectiveness of their input. To evaluate the output of participatory governance, Beierle (2002) coded information for 239 case studies on environmental decision-making. He found that stakeholder involvement resulted in higher decision quality for the majority of these cases, particularly when consensus among the participants was sought. Sultana and Abeyasekera (2007) analyzed 36 cases of community fisheries management in Bangladesh, some of which did not include public participation during the planning processes. They found participatory cases of governance to be more effective in terms of yielding more conservation measures and reducing conflicts between stakeholders. Newig and Fritsch (2009) conducted a meta-analysis of 47 cases of participatory decision-making in Western democracies to evaluate potential determinants of governance effectiveness. They found that environmental preferences of the actors, face-to-face and two-way communication, and multi-leveled governance systems influence environmental outputs. Similarly, Koontz (2005) conducted a multiple-case study, showing that high concerns for the environment, shared by already formed social networks, enhance the participatory contribution to policy-making.

\section{Methodology}

This thesis is a comparative study applying cs/QCA to a medium range size pool. The aim is to evaluate co-governance through establishing conditions, necessary and sufficient, for environmental policy to occur. 


\section{Case Selection}

Newig and Fritsch conducted a preliminary study through a meta-analysis of 47 case studies on environmental decision-making in developed countries to evaluate citizens' performance in governance. They argue that their regression models did not provide enough insights on the public contribution to governance effectiveness and started a new project called ECOPAG (Environmental Consequences of Participatory Governance - see bibliographical reference), collecting larger amount of case studies. This study defers to their on-going research project to select 16 case studies from their pool of 110 cases. The cases on environmental participatory decision-making, from North America, and Western Europe, generally share similar structural and process characteristics (i.e. local environmental problems, governance, though not exclusively, on local level, description of the problems and attempts for their solution, etc. ), as well as degrees of public participation. The study compares developed countries, as the democratic tradition of participatory governance developed there since 1960s, together with a shift towards post-material values, such as environmentalism (Mason 1999).

A moderate number of cases (16) are selected to facilitate QCA (Ragin 2008). Case selection is based upon participatory element, while also showing representativity in terms of scope of the projects (natural resource management, participatory planning, and sustainable community programs) and geographical spread (i.e. Canada, USA, Germany, Switzerland). Around half of the 110 cases report citizen involvement from North America, due to longer tradition of collaborative and inclusive eco-politics in the USA, compared to Europe (Newig and Fritsch 2008). Similarly, 6 out of the 16 selected cases concern US environmental management issues to ensure representativity from the pool, as well as to cover earlier participatory processes, as most of the American cases date back to the 20th century. The sample does not account for all types of participatory processes in the case study countries. However, it covers a broad spectrum of political and social issues, scales, types of participation, and governance arrangements.

The main criterion for selection is participation of non-state actors, based on Arnstein's "ladder of participation," which distinguishes between eight types of participation, grouped in two broader categories called "participation" and "non-participation." She argues that the latter category does not lead to citizen contribution to decision-making, as powerholders (governments and business) use it to claim representation of interests on behalf of the community (Arnstein 1969). Non-participation occurs when powerholders include citizens for the sake of inclusion or education, without consulting with them or giving them decision-making power, which constitutes the two lowest levels of the ladder. Only case studies, where participation exists at 
least in the form of consultation, some of which include negotiation and voting power, delegated to citizens, were selected.

Furthermore, case selection was based on information availability, provided in the case reports, with preference given to cases which contain primary data. Cases using secondary data sources, which do not describe the participatory events in detail, but rather focus on the environmental problem and its technical aspects, were excluded. Research techniques such as surveys and interviews of the participants in environmental governance, and observations of meetings enable comparison of the selected cases. They share similar characteristics such as background of the problem, timeline of participation events, analysis through surveys and/or interviews, and discussion and evaluation of participatory processes.

\section{Table 1. List of case studies analyzed}

\begin{tabular}{|c|c|c|c|}
\hline Case & Country & $\begin{array}{l}\text { Environmental } \\
\text { Issue }\end{array}$ & Reference \\
\hline Aargau Landfill Siting & Switzerland & waste incineration & Renn et al., 1998 \\
\hline Belmont Open Space Controversy & USA & spatial planning & Layzer, 2002 \\
\hline Ede High-Speed Railway & The Netherlands & railway construction & $\begin{array}{c}\text { Enserink and } \\
\text { Monnikhoff, } 2003\end{array}$ \\
\hline Great Bear Rainforest & Canada & $\begin{array}{c}\text { land and resource use } \\
\text { plan }\end{array}$ & Cullen, 2006 \\
\hline Homestake & USA & $\begin{array}{l}\text { uranuim mine } \\
\text { development }\end{array}$ & $\begin{array}{c}\text { Watson and } \\
\text { Danielson, } 1983\end{array}$ \\
\hline Kromme Rijn & The Netherlands & water management & Lamers et al., 2010 \\
\hline $\begin{array}{c}\text { Minnesota Water Qulity Citizen } \\
\text { Panel }\end{array}$ & USA & $\begin{array}{l}\text { agricultural impacts } \\
\text { on water quality }\end{array}$ & Crosby et al., 1986 \\
\hline $\begin{array}{c}\text { Monfalcone Regasification } \\
\text { Terminal }\end{array}$ & Italy & $\begin{array}{l}\text { construction of a } \\
\text { regasification } \\
\text { terminal }\end{array}$ & $\begin{array}{c}\text { Del Furia and } \\
\text { Wallace-Jones, } 1998\end{array}$ \\
\hline Neuss Mediation & Germany & $\begin{array}{l}\text { solid waste } \\
\text { management }\end{array}$ & $\begin{array}{l}\text { Fietkau and Weidner } \\
1995\end{array}$ \\
\hline San Juan Archipelago & USA & $\begin{array}{l}\text { marine ecosystem } \\
\text { management }\end{array}$ & $\begin{array}{l}\text { Evans and Klinger, } \\
2008\end{array}$ \\
\hline Scotland Wind Power & $\mathrm{UK}$ & wind power & Aitken, 2008 \\
\hline Spey River & UK & $\begin{array}{l}\text { river basin } \\
\text { management plan }\end{array}$ & $\begin{array}{l}\text { Blackstock and } \\
\text { Richards, } 2007\end{array}$ \\
\hline Sugarbush & USA & $\begin{array}{l}\text { dam construction for } \\
\text { snowmaking }\end{array}$ & $\begin{array}{l}\text { Fitzhugh and Dozier, } \\
1996\end{array}$ \\
\hline $\begin{array}{c}\text { Vancouver Island Generation } \\
\text { Project }\end{array}$ & Canada & $\begin{array}{l}\text { hydroelectric power } \\
\text { plant construction }\end{array}$ & Cruikshank, 2006 \\
\hline $\begin{array}{c}\text { West Hawai Marine Protected } \\
\text { Areas }\end{array}$ & USA & $\begin{array}{l}\text { marine area } \\
\text { protection }\end{array}$ & Capitini et al., 2004 \\
\hline Wuskwatim Generation Project & Canada & $\begin{array}{l}\text { hydroelectric dam } \\
\text { construction }\end{array}$ & Cruikshank, 2006 \\
\hline
\end{tabular}




\section{Method}

Literature on participatory environmental decision-making either follows a case study approach (Neidzialkowski et. al. 2012; Fietkau and Weidner 1995; Blackstock and Richards 2007) or performs large cross-case quantitative analysis (Newig and Fritsch 2009; Beierle 2009; Sultana and Abeyasekera 2007). By applying QCA, this study will conduct a cross-case analysis with the goal to identify conditions, necessary and sufficient, for a successful outcome to occur. Boolean algebra not fuzzy sets was applied due to lack of uniformly collected quantitative data, which would otherwise allow for accurate calibration of fuzzy sets variables. Calibration is conducted according to objective criteria, such as the presence or absence of four different variables, which can be traced in the case materials. The interpretation of the findings will draw upon extensive empirical evidence collected through archive research.

\section{Construction and Calibration of Variables}

The common outcome of environmental governance for the sixteen case studies is policy formulation. Since participating stakeholders, by adding new information and ideas, improve the quality of the decisions in most cases, any policy formulation with the absence of deadlock will be considered a success (Beierle 2002; Sultana and Abeyasekera 2007). Failure of environmental governance is considered to occur when consultation with stakeholders did not result in a policy formulation or a plan, submitted by a project developer (usually a company) was not approved by legislature. To determine the conditions necessary and sufficient for effective governance, four variables related to public participatory processes are constructed: multilevel governance, public participation in the decision-making process, presence of non-local actors (i.e. experts, business representatives, or members of an organization from a different region/city), and governmental agenda-setting. Newig and Fritsch (2009) find that multilevel governance leads to higher environmental outputs than polycentric governance. Multilevel governance is present in cases where more than one territorial tier is involved in policy-making or determines the legislative framework around the environmental problem, and absent when only one tier regulates and decides on the issue. Ensuring non-state actors' participation in the decisionmaking processes is widely advised as a best practice in environmental governance (Fiorino 1990; Laird 1993; Chase et al. 2004; Tippett et al. 2007, in Reed 2008). Presence of this variable is established when the public (or at least one participant from the public) has voting power or when governmental actors retreat from the decision-making process and the developer of a project and the public settle the dispute. Absence is when only governmental actors have voting and/or decision-making power. Presence of non-local actors on meetings includes at least one 
participant, who does not live or work in the region where an environmental problem originates (neutral observers of the processes are excluded), and absence means that only local actors are involved. This variable is related to a hypothesis that local citizens are mainly concerned with economic exploitation of natural resources, while non-local citizens favor conservation (Newig and Fritsch 2009). Agenda-setting by governmental actors influences not only the process of decision-making, but also the quality of its outcomes by maximizing information outputs (Newig and Fritsch 2012). Governmental agenda-setting is considered present when local governmental actors craft agenda for at least one meeting with stakeholders and absent when meetings are not initiated by authorities

\section{Findings}

The crispy set analysis provided one set of necessary and sufficient conditions leading to successful policy formulation:

govtagnd*multigovern

Governmental agenda-setting, combined with multilevel governance (coverage: 0.6364)

While this combination is not consistent enough to ensure a path of success for policy formulation, it provides guidelines for case clustering and understanding the mechanisms through which these variables affected the outcome.

The other two variables - public participation in the decision-making process and presence of non-local actors, did not produce any significant results in terms of policy formulation.

Citizen voting power or delegated power to make decisions, which will not require subsequent approval from the government, actually led to policy formulation, which emerged out of voting results, consensus, or compromise in Great Bear, Aargau, Spey River, and Wuskwatim Generation Project. For the remaining 5 cases, where the outcome was present but public participation in decisions was absent, policy was formulated as a result of strong citizen involvement in discussions and crafting projects. Although governments had the final decisionmaking power, their efforts for communication and coordination with non-governmental actors promoted consensual ideas of environmental policies.

Presence of non-local actors did not have significance for policy formulation, mostly because non-local actors were a small part of all participants and did not exercise much influence in discussions and decisions in none of these cases. The assumption that non-local citizens are 
more concerned with environmental outcomes, rather than economic issues, is not relevant for these cases. Instead, the findings support the value of local participation as a result of better understanding and knowledge of the problem.

\section{Findings Part I: Solution Analysis}

The solution covers six case studies with presence of the outcome and one case, which did not result in policy formulation. The elements which lead to success in the six cases are complexly intertwined and harder to identify, compared to those cases where failure to formulate policy was often due to concrete factors or circumstances (e.g. lack of cooperation between government officials and citizens, economic risks of a project, strong opposition, etc.). In those with successful outcomes, policy formulation was due primarily, but not exclusively, to the combination of multilevel governance and agenda setting by governments. The benefits, derived from this combination, can be inferred from archive research and secondary data, including observations of meetings and surveys and interviews of participants, collected by researchers and observers.

\section{Multilevel Governance}

The presence of multilevel governance facilitated policy formulation in two ways. Coordination between the different tiers of government eliminated a possible preponderance of the interests of one tier and ensured the provision of technical information and constant government support, when needed by participants. Legal provisions on national or supranational level, stipulating environmental protection and public participation in decisions, were applied to initiate the participatory processes and reach both consensual and more environmentally sustainable decisions.

Coordination between different tiers of government proved beneficial both for arranging efficient incorporation of the public in projects and success in policy formulation. For example, in Minnesota, to ensure effectiveness of the participatory process, the regional government chose as sponsors those state agencies that have the ability to influence events in the areas of water quality management. The coordination between the regional and national levels of government ensured the implementation of some of the recommendations, which were incorporated in a national bill (Crosby et al. 1986: 177). In Great Bear Rainforest, the provincial government was supported by an interagency planning team, made up of local and federal agencies, which provided technical analysis for the tables (Cullen 2006: 74). Similarly, in Neuss the district authorities cooperated with municipalities in launching a project, but with the aim to assign 
citizens to smaller groups and this cooperation ensured representative selection of different stakeholders (Fietkau and Weidner 1995). In Aargau, municipalities did not have enough resources to organize the process, so they benefitted from the help of a higher governing body and asked the Canton to assume responsibility for the project design and decision-making (Renn et al. 1998).

In some case studies, the coordination between different tiers, complemented by cooperation between governments and citizens, ensured that high-quality decisions were taken. In Minnesota, state agencies sponsored the work of citizens, who first took part in several regional panels, until they elaborated a set of recommendations and joined into one statewide panel to present their decisions. The government representatives allowed the regional panels more freedom to craft their recommendations, while the state panel was more strictly guided by the interested state agencies, thus helping reach a decision. The researchers who evaluated the participation arrangements concluded that the two-tiered approach showed how having good ties with local communities and requesting their input can become a way to influence statewide legislation (Crosby et al. 176). In Great Bear Rainforest, the native communities (First Nations) were encouraged to participate, based on their constitutional right to the land, requiring the government to consult with them and accommodate their interests (Cullen 63). The provincial government outreached their minimum legal duty to these communities by forming a partnership with First Nations representatives, aimed at negotiating a decision on land use. Participating citizens evaluated the recognition of First Nations as a distinct stakeholder as a positive aspect of the provincial government plan by citizens (Cullen 126). In Spey River, five national and regional authorities worked in close cooperation with stakeholders and were part of the citizen working groups, which led to adoption of the recommendations by all five organizations (Blacktock and Richards 2007: 500).

In several Europe based cases the legal provisions and implementation of EU directives led to public involvement in environmental problems and provided frameworks for more sustainable and consensual decisions. In Spey River, the European Water Framework Directive was implemented and citizens were invited to participate in crafting a River Basin Management Plan (RBMP) under Article 14, which calls for "active involvement of interested parties" in RBMPs (Blackstock and Richards 494). The participatory process was overseen by five regional and national authorities, who have statutory responsibilities under the European Habitats Directive (Blackstock and Richards 500). In Kromme Rijn, participation in water management planning was also a policy requirement from the European Water Framework Directive, stipulating 
integration of different interests related to water and "good ecological status for the water system" (Lamers et al. 2010). The implementation of the directive led to expansion of the functions of the regional water boards and effective process design and implementation, according to the majority of participants (citizens and authorities) and the researchers who evaluated the process. In a non-European case study - Great Bear Rainforest, the provincial government released a Protected Areas Strategy, which provided guidance to planning processes, crafting recommendations for protected areas (Cullen 53).

\section{Arranging Participatory Processes}

Multilevel governance arrangements, combined with governmental agenda, allowed for initiating and improving participatory processes. Agenda-setting is part of a larger strategy of governments, aiming at structuring participatory processes to achieve representation of different stakeholder groups and their values, open discussions, transparency of the processes, and, most importantly, to promote consensual decisions so that the resulting policies will not be challenged.

\section{i. Funding}

Since governments initiated participatory processes, in some case studies they also provided funding for implementation, including education, hiring external specialists, and implementation of the projects. Unlike private sponsorship, governmental funding aims at transparent selection of participants and decision-making processes and guaranteeing that policy will not favor business interests. For example, in Great Bear Rainforest, the provincial government, as well as the federal government provided the majority of funding to create an independent information body, which assisted the planning tables with information provision, recommendation of decision frameworks, and support for implementation (Cullen 81). In Neuss, funding to carry out mediation was provided by the Science Centre Berlin for Social Research center, which implemented the participation process together with the district government. The center drew funding from the German Ministry of Education, Science, Research and Technology (Fietkau and Weidner 5). While in most cases funding extended to hiring independent facilitators and covering costs for organization of participation, in Minnessotta government officials paid the participating panelists $\$ 75$ a day to compensate for the intensive and time-consuming sessions (Crosby et al. 175). In contrast to funding from companies (in Scotland Wind Power and Vancouvre Island Generation Project), in these cases citizens perceived government funding positively and raised no significant suspicions of conflicts of interest. 


\section{ii. Selection of Participants}

Participant selection influences the decision-making processes by assigning roles, such as information providers, influencers and decision-makers. Therefore, to achieve a thorough understanding about environmental problems, which can then be used for policy-making, selection should include variety of concerns and interests, chosen in a fair and transparent manner (Reed 2008). Furthermore, to ensure the effectiveness of the decision-making process, governments should tailor analysis strategies, which incorporate the participation of the most interested stakeholders, while informing those who are tangentially interested (Reed 2008).

To align with best practices, governments analyzed relevant stakeholders and ensured that selection was fair and equally representative of the different interests involved (Reed 2008: 2424). In Minnessotta, participants in the panels were selected from a pool of citizens who attended information meetings. However, in these meetings there was a predomination of concerns from only two groups - farmers and environmentalists. To ensure broader representation of interests, the regional government distributed surveys and then explained the selection process on the outset of each panel, which decreased suspicion about biased selection (Crosby et al., 175).

Selecting the relevant stakeholders and balancing representation of interests by either including or excluding certain groups guaranteed the legitimacy of the decision-making process in Neuss. Similarly to Minnessotta, in Neuss, numerous groups who had concrete and potential interest in solid waste management (e.g. environmental and economic organizations, citizens' initiatives, churches) were approached and informed about the reasons for mediation. Those representatives who had shown interest in the procedure were then invited to a public meeting, where they were given the right to select three representatives to participate in the mediation (Fietkau and Weidner 9). The mediator and the district staff, however, did not include disposal companies in the mediation to prevent business-related conflicts, as no company was selected to build the waste disposal facilities.

Stakeholder analysis as a tool to achieve systematic representation of all interests was used in Kromme Rijn to include a two tier involvement, where the stakeholders were given the role of decision-makers, while the less interested were kept informed. Unlike Neuss, in Kromme Rijn the regional government did not allow stakeholders to choose their representatives and took care of their selection, using a technique, called bull's eye approach, which categorizes stakeholders in an environmental issue from central to peripheral (Lamers et al. 2010). The regional government identified four groups, based on the degree of their involvement. The first two groups, made up 
of government officials, agricultural and environmental organizations, and recreation groups were directly involved in the project, while the second two groups - stakeholders with lower degree of interest and the general public, were only informed about the progress and occasionally consulted.

The common features of selection for all cases consisted in fair representation of citizens and making the distinction between stakeholders, who participated directly in crafting or improving the projects, and the general public, who were informed on the progress of the project, educated on the environmental problem, and allowed to raise concerns. The identification of stakeholders with central interests allowed governments to organize efficient participatory processes, in which small but carefully selected groups of citizens focused on problem-solving, avoiding pressure from publics while they presented the product of their efforts.

\section{iii. Benefits of Small Groups}

Working in small groups was one of the conditions for reaching consensual decisions, which then translated into policy formulation. Small groups allow all individuals to share their knowledge and opinion and, thus, prevent the potential loss of substantial information, which occurs in larger groups, when some members avoid participating (Blackstock and Richards 2007).

This element of participatory design, arranged by government staff, and its contribution to both consensus and stakeholder representation was best illustrated in Spey River. Regional and national authorities broke down the multitude of participants by designating five working groups, each responsible for different environmental aspects of river basin management (i.e. water quality, agriculture and forestry, fisheries management, etc.). They decided to include representatives of interest groups and statutory bodies for their expertise and local knowledge. Then they developed a plan, involving five stages to make sure that the river basin management plan is prepared by the working groups and then approved by the citizens, who attended the final consultation meeting. Interviews show that three-quarters of the stakeholders praised the discursive process, initiated by government officials, for encouraging potential solutions to be assessed from a number of perspectives (Blackstock and Richards 502). Furthermore, deliberation within the working groups, encouraged by government staff, aided consensus, for example through preparing a guide on control of river waters, which eliminated disagreements over handling engineering works in the river basin (Blackstock and Richards 503). 
The main benefits of working in small groups in Aargau and Kromme Rijn included open discussions with greater variety of views than larger meetings usually permit. In Kromme Rijn the involved stakeholders appreciated their exclusiveness from the general public, stating that working in small groups gave them a sense of safety and enabled them to discuss directly and openly (Lamers et al. 2010). In Aargau, the small working groups also promoted communication, as they incorporated the input of participants who did not usually speak in larger meetings (Renn at al. 1998). In Great Bear Rainforest and Neuss, one of the main aims of government officials was to ensure representation of interests and consensus. The district government in Neuss organized nine mediation large sessions, complemented by smaller meetings with deliberately fewer stakeholders, attempting to fulfill both goals (Fietkau and Weidner 6). In Great Bear Rainforest, government officials promoted consensus by first dividing the region into north and south planning areas during the first planning table and then addressing the whole region during the following planning table, so that local participants can consider their own sub region, at the same time having a say on the whole plan (Cullen 87).

\section{iv. Procedural Rules}

Small group discussions were facilitated by creating procedural rules and appointing independent specialists, most commonly, mediators. The development of ground rules enables discussions, which will not be disrupted by procedural disagreements. Basic and rudimentary rules are preferred to detailed and long procedural ones, as the latter can stifle participants' creativity (Weidner and Fietkau 31).

In Aargau, for instance, government officials discussed the rules of discourse and the desired procedure for making final decisions. All participants adopted these rules unanimously and requested each session to be facilitated by an independent moderator, which subsequently guaranteed a fair consensual procedure (Renn et al. 1998). In Neuss the same combination, complemented by officials' willingness to make a compromise, which partially incorporated the demands of a particular group of stakeholders, led to successful policy formulation. The mediator proposed rules to the participants, weeks before the mediation began, to prevent procedural conflicts. Although the process did not end with a consensus, as environmental pressure groups and the Green party did not agree that waste should be incinerated, the district officials managed to partly alleviate Greens' concerns by reducing incineration by $78 \%$, compared to previous years. Therefore, the officials' aim to ensure mediation was successful and resulted in partial compromise in favor of ecological demands, since consensus was impossible. Even though the outcome of the mediation received mixed responses by the participants, none 
of them agreed that a more transparent and satisfactory decision could have been taken without mediation (Fietkau and Weidner 43). Similarly, in Great Bear Rainforest 86\% of the participants stated that the presence of an independent mediator improved the effectiveness of the planning process. (Cullen 114-115).

\section{v. Agenda-setting}

Meetings and workshops in small required agendas either set by one or more government level or in cooperation with mediators or stakeholders. Agendas facilitated the interaction between governmental and non-governmental actors, thus allowing participative decisions to translate into policies. Usually, agendas were fixed at the first stages of the participatory arrangements to ensure sufficient information and discussion of a wide range of problems. As the process advanced, they were subsequently adjusted in accordance with the decision makers' needs. In Minnesota, agendas were crafted with the help of the participating citizens and constantly adjusted to match their changing needs for flexibility to articulate their preferences, on one hand, and for structured environment, when they faced difficulties in problem definition and decisionmaking, on the other. At the beginning of the organization stage, government officials faced the challenge of problem definition, pertaining to agricultural impacts on water quality. State agencies, which were sponsors of the project, demanded to narrow down of the scope of the problem, but they did not reach consensus on which aspects should be left for discussion. Government officials then solved this agenda-setting problem presenting the whole range of environmental impacts and, thus, allowed the participating citizens to articulate their values and concentrate on which environmental aspects they considered important. To ensure that staff presentations were accurate and bias-free, officials held a dry-run in front of all stakeholders. Additionally, they allowed their preliminary agenda to be examined by all participants. The panelists made new suggestions and, subsequently, the content of the agenda was modified. After the panelists were educated, the regional government set the agenda by selecting the state agencies, deemed to have expertise, to present alternative solutions. The panelists chose the solutions according to their preferences and directed the staff in crafting agenda for the following days. When the final decision had to be taken, panelists found it difficult to reach conclusions on specific set on recommendations. The staff prepared several frameworks the panelists could use in formulating the final decision. Panelists approved the frameworks and based their final report on them (Crosby et al. 174-175).

Crafting a flexible agenda together with citizens was outlined as good practice in Minnesota, as it guaranteed transparent decision-making, which served for passing a national bill. Another way of 
improving transparency and avoiding potential conflicts is through seeking approval of the rules and agendas from participating citizens, as in Neuss and Kromme Rijn. In both cases regional officials crafted agendas, together with independent facilitators, specifying the aims of each workshop, meeting and presentation, and decided which groups took part in them. Their efforts proved beneficial to the centrally involved participants, because they needed guidance. Generally, citizens in Kromme Rijn responded in interviews that they were very satisfied with the openness of the process, the extent to which they had influence, and how government reduced conflicts of interests (Lamers et al. 2010). Participants in Neuss mediation were also satisfied by the transparency of processes and specifically pointed out the mediator's contribution to fair decision-making (Fietkau and Weidner 35).

Mediators also aided with agenda-setting in Great Bear Rainforest and, together with a governmental interagency team, ensured that citizens' recommendations on land use of all planning tables were incorporated in the final planning document. Participants were not consulted on the agenda, which did not have a negative impact on the final decision in this case. The province promoted fairness in educating participants by developing analysis guidelines to ensure that all planning tables had access to the same information. To reach consensus the provincial staff applied a variety of techniques, such as negotiation, consultation, fact-finding, and mediation (Cullen 56). The majority of the participants who were interviewed stated that governmental agenda setting proved beneficial by providing clear rules (71\%) and sufficient training (79\%), and 93\% agreed that the staff lead the process in a "neutral and unbiased manner" (Cullen 114-115). Overall, 93\% of the participants, including government officials, stated that the process was a positive experience and 85\% perceived it as a success (Cullen 119126).

\section{Combination of Conditions}

The combination of multilevel governance and governmental agenda-setting allowed for initiating and improving participatory processes. Specifically, the established communication and coordination between officials from different tiers of government or a specific regulatory framework led to obtaining funding for participatory processes and policy implementation. Once participation was arranged, officials crafted agendas, occasionally with the help of independent facilitators or participating stakeholders, containing procedural rules and aiming to incorporate all concerns and information about a particular environmental problem. Agenda-setting facilitated decision-making by structuring and directing discussions, while coordination between different tiers of government, as well as between them and participating citizens, enabled the 
results of these discussions to gain wider acceptance by both governmental and nongovernmental actors, and then translate into policies.

\section{Monfalcone - a special case}

Monfalcone stands out as the only case study, in which the combination of multilevel governance and governmental agenda was present and, yet, policy was not formulated. Unlike in the other cases of energy-related environmental issues, not a private project developer, but the municipality of Monfalcone organized and led the participatory process. Investigating the cause for the lack of success reveals that the project (construction of a regasification terminal) gained the consensus of the citizens, immediately involved in its evaluation, but was abandoned due to the negative results of a referendum. Therefore, the process of decision-making, prior to consultation through the referendum, was not problematic and the combination of multilevel governance and governmental agenda aided consensus within the working groups. Del Furia and Wallace-Jones (1998) identified multiple benefits from the involvement of the municipal government. For example, government officials arranged information campaigns to address citizen concerns, attempted to reach wider public by entering discussions with citizens in favor and against the project, and encouraged small meetings so that participants will express their values and interests. Their efforts were complemented by the Environmental Impact Assessment (EIA) - a decision-supporting procedure, based on Directive 85/337/EEC, which was enforced by the Italian government in 1990 (Del Furia and Wallace-Jones 2). EIA foresees that information, assessing the potential impacts of a project on the environment, is used to support decisions. In Monfalcone, government officials sought feedback about the quality of EIA from citizens and their input determined the final decision. By following EIA recommendations and, thus, devolving more power to the public than usually in such procedures in Italy, the government ensured transparent two-way communication and significant changes to the project design, which arose from consensus (Del Furia and Jones 26). However, these efforts did not translate in a specific policy, because the majority of citizens voted against the project, which could have been prevented, if the Italian government would have announced the judgment on environmental compatibility prior to the referendum.

\section{Conclusion}

This thesis assesses the contribution of citizen participation within environmental governance arrangements. Applying cs/QCA as a new method for analyzing case studies of local environmental problems, this research aims at identifying conditions necessary and sufficient for 
local and regional decision-making structures to reach successful policy formulation. The findings suggest that environmental policy formulation is dependent upon governmental agendasetting and multilevel governance. Depending on the case studies, fixed or flexible agendas, combined with legal provisions, implementation of EU directives, and coordination on different government levels, create frameworks for taking environmental decisions, which enable not only inclusion, but also contribution of citizens. These findings are useful for identifying elements of good practices within these cases, which promote the incorporation of different interests and values into consensual decisions.

Environmental problems have a complex nature, as they involve a multiplicity of actors and interests as well as intricate interlinkages of technological, societal, and environmental factors. Therefore, no single way of evaluating the effectiveness of environmental decisions exists. This thesis assesses the quality of environmental governance by focusing on the dynamics of decisionmaking and procedural legitimacy, based on inclusion and legitimate representation. The main assumption behind this method of evaluation suggests that local participation enhances decisionmaking processes, because factual knowledge about local conditions is integrated in their solutions, presuming that those who are closest to the problem have developed thorough understanding about it.

The thesis calls for further investigation of environmental governance in terms of the effectiveness of policy implementation. The field of environmental governance can benefit from establishing links between how environmental policies are effectively interpreted and applied to solve complex environmental issues. To make further evaluations of public participation, research can focus on case studies, in which coordination efforts between governmental actors and citizens extend beyond policy formulation to involve citizens in the implementation of the solutions. 


\section{Bibliography}

Aitken, Mhairi. 2008. "Power and Windpower: Exploring Experiences of Renewable Energy Planning Processes in Scotland.” PhD thesis, Robert Gordon University.

Arnstein, Sherry. 1969. "A Ladder of Citizen Participation." Journal of the American Institute of Planners 26: 216-233.

Beierle, Thomas. 2002. "The Quality of Stakeholder-Based Decisions: Lessons from the Case Study Record.” Risk Analysis 22: 739-749.

Betsill, Michele, et al. 2006. International Environmental Politics. Hampshire: Palgrave.

Blackstock, Kirsty, and Caspian Richards. "Evaluating Stakeholder Involvement in River Basin Planning: A Scottish Case Study.” Water Policy 9 (2007): 493-512.

Bressers, Hans, and Walter Rosenbaum, eds. 2003. Achieving Sustainable Development. The Challenge of Governance Across Social Scale. Westport: Praeger.

Capitini et al. 2004. "Competing Perspectives in Resource Protection: The Case of Marine Protected Areas in West Hawai'i." Society and Natural Resources 17: 763-778.

Cooke, Bill, and Uma Kothari, eds. 2001. Participation: The New Tyranny? London: Zed Books.

Crosby et al. 1986. "Citizen Panels: A New Approach to Citizen Participation." Public Administration Review 46(2): 170-178.

Cruikshank, Aaron. 2006. "Assessing Public Participation in Canadian Public Electric Utilities." Master of Public Policy. Simon Fraser University.

Cullen, Andrea. 2006. "The Central Coast Land and Resource Management Plan: An Evaluation of Collaborative Planning in British Columbia." Master of Resource Management Thesis, School of Resource and Environmental Management, Simon Fraser University.

Del Furia, Luca, and Jane Wallace-Jones. 1998. "The Effectivenes of Provisions and Quality of Practices Concerning Public Participation in EIA Procedures in Italy and the UK."

Driessen, Peter, et al. 2012. "Towards a Conceptual Framework for the Study of Shifts in Modes of Environmental Governance - Experience from the Netherlands." Environmental Policy \& Governance 22(3): 143-160.

Enserink, Bert, and René Monnnikhof. 2003. "Information Management for Public Participation in Co-design Processes: Evaluation of a Dutch Example." Journal of Environmental Planning and Management 46(3): 315-344.

Evans, Kristen, and Terry Klinger. 2008. "Obstacles to Bottom-Up Implementation of Marine Ecosystem Management.” Conservation Biology 22(5): 1135-1143.

Farrington, John. 1998. "Organisatonal Roles in Framer Participatory Research and Extension: Lessons from the Last Decade.” Natural Resource Perspectives 27. 
Fietkau, Hans-Joachim, and Helmut Weidner. 1995. "Environmental Mediation: The Mediation Procedure on the Waste Management Plan in the District of Neuss, North-Rhine Westphalia Initial Results of the Companion Social Science Research." Schriften zu Mediationsverfahren im Umweltschutz 10: 1-70.

Fischer, Anke, and Juliette Young. 2007. "Understanding Mental Constructs of Biodiversity: Implications for Biodiversity Management and Conservation.” Biological Conservation 136: 271-282.

Fitzhugh, John, and Daniel Dozier. 1996. "Finding the Common Good. Sugarbush Water Withdrawal."

Folke, Carl, et al. 2005. "Adaptive governance of social-ecological systems." Annual Review of Environment and Resources 30: 441-473. EBSCO.

Glasbergen, Peiter, ed. 1998. Co-operative environmental governance: public-private agreements as a policy strategy. Dordrecht: Kluwer Academic.

Hempel, Lamont. 1996. Environmental governance: the global challenge. Washington, D.C.: Island Press.

Kooiman, Jan, et al, eds. 2005. "The governance perspective." Fish for life: interactive governance for fisheries. Amsterdam: Amsterdam University Press.

Koontz, Tomas. 2001. "What Do We Know and Need to Know about the Environmental Outcomes of Collaborative Management?” Public Administration Review 66: 139-152.

Lamers et al. 2001. "Beyond Dry Feet? Experiences from a Participatory Water-Management Planning Case in The Netherlands." Ecology and Society 15(1): 1-14.

Layzer, Judith. 2002. "Citizen Participation and Government Choice in Local Environmental Controversies.” Policy Studies Journal 30(2): 193-207.

Lemos, Maria, and Arun Agrawal 2006. "Environmental governance." Annual Review of Environment and Resources 31: 297-325. EBSCO.

Mason, Michael. 1999. Environmental Democracy. London: Earthscan Publications Ltd.

Meadowcroft , James. 1999. "Cooperative Management Regimes: Collaborative Problem Solving to Implement Sustainable Development.” International Negotiation 4: 225-254. EBSCO.

Newig, Jens, and Oliver Fritsch. 2009. "Environmental Governance: Participatory, Multi-level and Effective?" Environmental Policy \& Governance 19(3): 197-214. EBSCO.

Newig, Jens, and Oliver Fritsch. 2012. "More Input - Better Output: Does Citizen Involvement Improve Environmental Governance?" Environmental Governance: The Challenge of Legitimacy and Effectiveness. Eds. Karl Hogl, Eva Kvarda, , Ralph Nordbeck, and Michael Pregernig. Chetelham: Edward Elgar Publishing Limited.

Newig, Jens, et al. 2012. "Environmental Consequences of Participatory Governance - A Comparative Meta-Analysis of Case Studies in Environmental Decision-Making." 
Newig, Jens, et al. 2008. "The Role of Formalisation, Participation and Context in the Success of Public Involvement Mechanisms in Resource Management." Systemic Practice and Action Research. 21: 423-441.

Niedzialkowski, Krzysztof, et al. 2012. "Participation and Protected Areas Governance: the Impact of Changing Influence of Local Authorities on the Conservation of the Bialowieza Primeval Forest, Poland." Ecology and Society 17(1). EBSCO.

Paavola, Jouni. 2007. "Institutions and environmental governance: a reconceptualization." Ecological Economics 63(1): 93-103.

Plummer, Ryan, et al. 2013. "Adaptive comanagement and its relationship to environmental governance.” Ecology and Society 18(1): 1-21.

Ragin, Charles. 1989. The Comparative Method: Moving Beyond Qualitative and Qunatitative Strategies. California: University of California Press.

Ragin, Charles. 2008. Redesigning Social Inquiry: Furay Sets and Beyond. Chicago: The University of Chicago Press.

Reed, Mark. 2008. "Stakeholder Participation for Environmental Management: A Literature Review.” Biological Conservation 141: 2417-2431.

Renn at al. 1996. "Procedural and Substantive Fairness in Landfill Siting: A Swiss Case Study."

Rydin, Yvonne, and Mark Pennington. 2000. "Public Participation and Local Environmental Planning: The Collective Action Problem and the Potential of Social Capital." Local Environment 5(2): 153-169.

Sultana, Parvin, and Savitri Abeyaskera. 2007. "Effectiveness of Participatory Planning for Community Management of Fisheries in Bangladesh." Journal of Environmental Management 86: 201-213.

The World Bank Group. Beyond Economic Growth. Glossary.

Toikka, Archo. 2010. "Exploring the Composition of Communication Networks of Governance - a Case Study on Local Environmental Policy in Helsinki, Finland.” Environmental Policy and Governance 20: 135-145. EBSCO.

Vonkeman, Gerrit, ed. 2000. Sustainable Development of European Cities and Regions. The Netherlands: Kluwer Academic Publishers. Print.

Watson, John, and Luke Danielson. 1983. "Environmental Mediation.” Natural resources Lawyer 15(4): 687-723. JSTOR.

Wesselink Anna, et al. 2011. "Rationales for public participation in environmental policy and governance: practitioners' perspectives." Environment and Planning A 43(11): 2688 - 2704. 


\section{Appendix}

\section{Truth Table}

\begin{tabular}{|l|r|r|r|r|r|r|}
\hline 1 & caseid & dcmaking & multigov $\in$ nonloc & govtagnd & poliform \\
\hline 2 & neuss & 0 & 1 & 1 & 1 & 1 \\
\hline 3 & great & 1 & 1 & 0 & 1 & 1 \\
\hline 4 & vancouvre & 0 & 1 & 1 & 0 & 0 \\
\hline 5 & aargau & 1 & 1 & 1 & 1 & 1 \\
\hline 6 & monfalcone & 1 & 1 & 0 & 1 & 1 \\
\hline 7 & scotland & 0 & 0 & 1 & 0 & 0 \\
\hline 8 & minnessotta & 0 & 1 & 0 & 1 & 1 \\
\hline 9 & kromme & 0 & 1 & 0 & 1 & 1 \\
\hline 10 & sugarbush & 1 & 1 & 0 & 0 & 1 \\
\hline 11 & belmont & 1 & 0 & 0 & 0 & 0 \\
\hline 12 & westhawaii & 0 & 1 & 0 & 0 & 1 \\
\hline 13 & homestake & 0 & 0 & 0 & 0 & 1 \\
\hline 14 & spey & 1 & 1 & 1 & 1 & 1 \\
\hline 15 & ede & 0 & 1 & 1 & 0 & 0 \\
\hline 16 & wuskwatim & 1 & 0 & 1 & 0 & 1 \\
\hline 17 & sanjuan & 0 & 1 & 0 & 0 & 1 \\
\hline
\end{tabular}

\section{Cs/QCA Software Output}

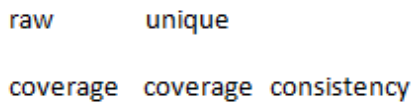

Cases with greater than 0.5 membership in term govtagnd* multigovern: neuss $(1,1)$,

great $(1,1)$, aargau $(1,1)$, monfalcone $(1,1)$,

minnessotta $(1,1)$, kromme $(1,1)$, spey $(1,1)$ 